\title{
WIETNAM
}

\section{Ta Tuan Minh}

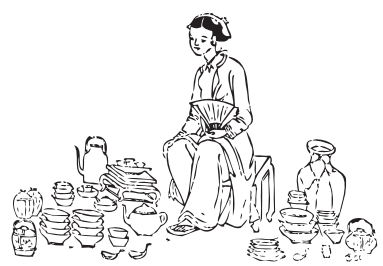

\section{ROZUMIENIE DEMOKRACJI I CZYNNIKI STYMULUJĄCE JEJ ROZWÓJ W WIETNAMIE}

Od dziesięcioleci demokracja i sprawiedliwość społeczna stanowią przedmiot dyskusji w kręgach akademickich, a także cel większości społeczeństw. Niezmiennie pozostają też jedną z centralnych kwestii obecnych w różnych dyskursach o stosunkach międzynarodowych oraz polityce wewnętrznej, zwłaszcza po zakończeniu zimnej wojny. Społeczeństwa się zmieniają, w rezultacie czego ewoluują również teoretyczne ramy, w których dyskutowane są zagadnienia demokracji i sprawiedliwości społecznej. Nie jest moim zamiarem analizowanie w tym miejscu współczesnych teorii odnoszonych do demokracji, jako że poświęca im się wiele uwagi na innych forach. Przedstawię tu raczej opinie prezentowane w latach ostatnich w Wietnamie na ten temat $\mathrm{w}$ dyskusjach toczonych na łamach prasy oraz w innych publikacjach. Kwestią najbardziej interesującą są formy zachodzenia procesów demokratyzacji w państwie rządzonym przez partię komunistyczną.

W kontekście procesów politycznych współczesnego świata zagadnienie demokratyzacji w państwie rządzonym przez partię komunistyczną bywa ledwo wzmiankowane. Natomiast ja chciałbym wykazać, że przemiany demokratyczne są tam możliwe, jeśli istnieją zarówno czynniki wewnętrzne, jak i zewnętrzne wystarczająco silne, by stymulować jej rozwój. Obejmują one m.in. zmianę politycznego nastawienia liderów partii komunistycznej, pojawianie się takich sił społecznych, jak: bardziej otwarte media, organizacje pozarządowe, zaangażowane grupy społeczne, a także wpływ integracji gospodarczej i globalizacji. Podejmuję również próbę wskazania na niektóre z ograniczeń demokracji w Wietnamie. Podsumowując, stwierdzam, że demokratyzacja w Wietnamie jest, moim zdaniem, możliwa, chociaż obecnie jej wprowadzanie jest w znacznej mierze jeszcze procesem odgórnym. 


\section{Idea demokracii}

W Wietnamie demokracja nie jest koncepcją nową. W swojej Proklamacji niepodległości z 2 września 1945 r. [Prezydent] Ho Chi Minh zacytował Deklarację niepodległości Thomasa Jeffersona i skrytykował francuski rząd za brutalność w sprawowaniu władzy oraz negowanie wolności i demokracji w swojej kolonii ${ }^{1}$. Decyzja o przeprowadzeniu pierwszych w dziejach Wietnamu wyborów powszechnych, zaledwie cztery miesiące po narodzinach Demokratycznej Republiki Wietnamu, wydawała się wskazywać, że ówczesny rząd tymczasowy sprawować będzie rządy demokratyczne.

Już sama nazwa nowo powstałego niepodległego państwa świadczyła o systemie politycznym opartym na powiązaniu zasad demokratycznych i republikańskich. Ho Chi Minh był pierwszym liderem, który stworzył podstawy do zaprowadzenia demokracji w Wietnamie. Zdefiniował on demokrację w prosty sposób: demokracja oznacza rządy ludu. Swoje idee zawarł w Konstytucji z 1946 r., której artykuł 1 stwierdza, że cała władza należy do ludu Wietnamu, bez względu na pochodzenie, płeć, status społeczny czy wyznanie religijne. W tym sensie wszystkie organy władzy oraz cała władza spoczywają w rękach ludu². Od momentu powstania niepodległego Wietnamu przyjmowano więc w teorii takie koncepcje demokracji, które nie różniły się znacząco od współczesnego rozumienia tego terminu. W praktyce wietnamscy politycy śledzili uważnie debaty toczące się w świecie o problemie demokracji i wyciągali z nich pewne wnioski:

- Lud jest traktowany jako źródło i podmiot władzy państwowej.

- Wszystkie władze oraz ciała rządowe powinny być wyłaniane oraz usuwane w drodze wolnych i sprawiedliwych wyborów przez tajne głosowanie.

- Instytucje polityczne oraz samo państwo muszą opierać się na ustawach oraz sprawować rządy prawa.

- Trójpodział władz powinien być podstawową zasadą, a kumulowanie wpływów przez jakiejkolwiek organ powinno być wykluczone; władza powinna być natomiast podzielona między różne podmioty oraz zdecentralizowana.

- Państwo powinno sprawować swą władzę w sposób otwarty i transparentny.

- Państwo musi współpracować ze społeczeństwem obywatelskim, by ułatwić obywatelom udział w funkcjonowaniu państwa, a także kontrolę oraz krytykę działań prowadzonych przez państwo.

- Lud powinien posiadać wolny dostęp do informacji i mediów masowych.

${ }^{1}$ Ho Chi Minh, Selected Works, Vol. 4, Nha Xuat Ban Chinh Tri Quoc Gia, Hanoi 1995, s. 1-4.

2 Ibidem, s. 698. 
- Mniejszość powinna podporządkowywać się decyzjom większości, chociaż jednocześnie większość powinna szanować i chronić prawa mniejszości.

Niektórzy autorzy wietnamscy utrzymują, że w istocie demokracja - w szerokim sensie - sprowadza się do uformowania gospodarki rynkowej, konstytucyjnego porządku politycznego w państwie i społeczeństwa obywatelskiego ${ }^{3}$.

W dzisiejszym Wietnamie koncepcje demokracji zazwyczaj zawierają trzy elementy składowe. Po pierwsze, demokracja oznacza posiadanie przez obywateli praw gospodarczych, na które składają się: (a) zakładanie instytucji oraz przedsiębiorstw gospodarczych i oddanie gospodarki pod kontrolę obywateli, by służyła ona ich prawnie usankcjonowanym potrzebom i interesom; (b) ustanowienie gospodarczych mechanizmów, w których wszyscy pracownicy mogą posiadać prawo do własności i zarządzania w różnych formach, na przykład pracownicy mogą nabywać akcje przedsiębiorstw; (c) ochrona i wsparcie dla inicjatyw pracowników oraz ich udział w tworzeniu biznes planów i w działalności firmy; (d) promocja gospodarki rynkowej dla zapewnienia równej konkurencji oraz korzyści konsumentom. Krótko mówiąc, pierwszy element stanowi kompozycję prawie wszystkich czynników gospodarki rynkowej, gdzie występuje prywatna własność nieruchomości i przedsiębiorstw, funkcjonują wolny handel i inwestycje zarówno w wymiarze krajowym, jak i zagranicznym.

Po drugie, demokracja oznacza posiadanie przez obywateli praw politycznych, które obejmują wolność fizyczną i osobiste bezpieczeństwo, ochronę przed torturami, prawną reprezentację w każdym miejscu, równość wobec prawa, wolność myśli i wypowiadania się, wolność zrzeszania się, wolność religii i wyznania oraz udział w sprawowaniu władzy. Obecnie prawa polityczne obywateli przejawiają się w następujących formach: (a) prawa do posiadania prawdziwie demokratycznego państwa, którego władze są wyłaniane w głosowaniu powszechnym, a samo państwo służy obywatelom do zapewnienia ich usankcjonowanych praw; (b) rozszerzania praw obywateli do uczestnictwa w działaniach państwa, przy czym obywatele mają prawo dyskutowania wszystkich kwestii dotyczących bezpośrednio ich dóbr; zakres, w jakim obywatele uczestniczą w procesie politycznym i społecznym oraz efektywność takiego uczestnictwa określa poziom demokracji; (c) posiadania przedstawicieli ludu wybieranych w prawdziwie demokratyczny sposób, co oznacza zwiększanie zakresu władzy ludu oraz determinuje, w jaki sposób obywatele mogą dokonywać swoich wyborów.

Po trzecie, demokracja oznacza panowanie ludu w społeczeństwie obywatelskim, co obejmuje szeroki zakres praw, takich jak: zakaz wszelkiej dyskrymina-

${ }^{3}$ Dau Xuan Luan and Nguyen Minh Tuan (red.), Dan Chu Va Thiet Che Dan Chu O Viet Nam [Demokracja i instytucje demokratyczne w Wietnamie], Nha Xuat Ban Quan Doi Nhan Dan, Hanoi 2006 , s. 72-73. 
cji, prawo do wolności osobistej i bezpieczeństwa, równą ochronę przez prawo, humanitarne traktowanie w przypadku aresztowania, równość w związku małżeńskim, prawo do zatrudnienia oraz równość warunków pracy, a także prawo do edukacji ${ }^{4}$. W pewnym sensie pokazuje to, na ile ludzie są równo traktowani wobec prawa. Należy zaznaczyć, iż coraz większą uwagę zwraca się na kwestie związane z płcią. Pozycja kobiet w wietnamskim społeczeństwie uległa istotnej zmianie. Na przykład reprezentacja kobiet w obecnym Zgromadzeniu Narodowym wynosi 25,76\% i jest jedną z najwyższych w Azji, przy czym aż 91,4\% spośród nich stanowią absolwentki uniwersytetów oraz wyższych uczelni ${ }^{5}$.

Demokracja w Wietnamie przybiera dwie różne formy: demokracji przedstawicielskiej oraz demokracji bezpośredniej. Demokracja przedstawicielska jest formą, w ramach której obywatele wykonują swoje prawa polityczne za pośrednictwem społeczno-politycznych organizacji, jak: Związek Kobiet, Związek Młodzieży, Związek Rolników, Związek Pracy i innych stowarzyszeń zawodowych. Obywatele mogą również wykonywać swoje polityczne prawa poprzez swoich przedstawicieli w lokalnych/miejskich radach oraz w Zgromadzeniu Narodowym. Demokracja bezpośrednia jest natomiast realizowana przez obywateli, którzy bezpośrednio wyrażają swoje opinie i uczestniczą w politycznym procesie decyzyjnym odnoszącym się do wspólnych kwestii dotyczących ich wspólnot czy społeczności. Demokracja bezpośrednia realizowana jest zazwyczaj w małych wspólnotach, takich jak: wioski, szkoły, fabryki, biura władz lokalnych. Innymi słowy, obywatele mogę podejmować decyzje w zakresie różnych kwestii dotyczących dobrobytu ich samych oraz ich wspólnoty, jak również kontrolować funkcjonowanie organów władzy (patrz dyskusje o demokracji na poziomie lokalnym). Na poziomie ogólnokrajowym obywatele mogą bezpośrednio oddawać swój głos w plebiscycie lub wyborach powszechnych. Jest to najwyższa forma wyrażenia ich praw politycznych ${ }^{6}$.

Demokratyzacja, tak jak postrzega się ją obecnie w Wietnamie, jest procesem implementacji demokracji, a mianowicie wprowadzania wartości demokratycznych do życia społecznego, urzeczywistniania ich w życiu obywateli oraz stosunkach społecznych i zarządzaniu. Centralnym zagadnieniem demokratyzacji jest ustanowienie demokratycznych praw dla potwierdzenia i zagwarantowania całej władzy należącej do ludu. Wola ludu, jego aspiracje, interesy oraz władza powinny być ponad wszystkim. Demokratyzacja implikuje występowanie konfliktów spo-

${ }^{4}$ Pham Ngoc Quang, On Democracy in Some Areas in Vietnam, „Political Theory Review” 2008, No. 11, s. 29-33.

${ }^{5}$ Nguyen Thi Mai, Ket Qua Bau Cu Quoc Hoi Khoa XII Nhin Tu Goc Do Gioi [Wyniki wyborów 12 sesji Zgromadzenia Narodowego z perspektywy płci], The National Committee for the Advancement of Women in Vietnam, http://www.ubphununcfaw.gov.vn/index.asp?lang=V\&func=newsdt\& CatID $=117 \&$ newsid $=1651 \& \mathrm{MN}=65$.

${ }^{6}$ Luan i Tuan, op.cit., s. 75-76. 
łecznych, w które włączyć się może każda osoba i organizacja. Mają one na celu dopuszczenie krytycznej oceny oraz eliminację wszystkich form naruszeń demokracji, co powinno być możliwe zarówno dla samych obywateli, jak też dla całego społeczeństwa. To powinno również wprowadzać niezbędne korekty do demokracji symbolicznej, w tym nawet w jej skrajnych wersjach, a także ograniczać anarchiczną wolność.

Demokratyzacja jest prawem tylko wtedy, kiedy przynosi pozytywne rezultaty, dzięki którym społeczeństwo pozostaje stabilne i rozwinięte. Promowaniu demokracji musi więc towarzyszyć wspieranie rządów prawa, zapewnianie bezpieczeństwa obywatelom i zabezpieczenia społecznego. Zaburzenie ładu oraz niepokoje społeczne nie zapewniają demokracji, raczej mogą być szkodliwe dla norm społecznych i zasad, a także dla demokratycznych osiągnięć już zdobytych przez społeczeństwo ${ }^{7}$.

\section{Czynniki stymulujące demokratyzacię}

Po zjednoczeniu w 1975 r. Wietnam zamknął się przed światem zewnętrznym i pozostawał przez wiele lat w izolacji. W systemie komunistycznym koncepcja demokracji w postaci praktykowanej na Zachodzie była obca większości obywateli, tym bardziej że nie znali jej z wcześniejszych etapów historii. Demokracja znikła także jako temat dyskursu społecznego. Być może jedynym pojęciem demokracji w tamtym okresie był „demokratyczny centralizm”, tworzący główny komponent komunistycznych teorii i ideałów. W rzeczywistości wszystkie decyzje podejmowane przez partię rządzącą stawały się „obowiązującym prawem” i miały charakter ostateczny. Niewielki był też margines swobody do wyrażania odmiennych poglądów. Funkcjonowanie państwa oraz rządu zostało zdominowane całkowicie przez partię, co oznaczało konieczność postępowania zgodnie z wytyczonymi przez nią kierunkami i według jej instrukcji. Zgromadzenie Narodowe miało stanowić najwyższy organ ustawodawczy, lecz w istocie jego funkcje sprowadzały się jedynie do zatwierdzania wszystkiego, czego wymagała partia rządząca. Sytuacja ta zaczęła ulegać zmianom dopiero wraz z przyjęciem w 1986 r. polityki doi moi (odnowy), która rozpoczęła także procesy demokratyzacji. Ich podstawą były reformy polityczne zainicjowane przez Komunistyczną Partię Wietnamu (KPW).

W przeciwieństwie do rozpowszechnionych na Zachodzie poglądów głoszących, że Wietnam podjął jedynie reformy gospodarcze, a sfera polityczna pozostała nietknięta, jego przywódcy od dawna są świadomi faktu, iż reformy gospo-

\footnotetext{
${ }^{7}$ Ibidem, s. 151.
} 
darki muszą być prowadzone równolegle z reformami politycznymi. Istnieje więc zrozumienie, że promowanie demokracji jest potrzebne. Proces ten wietnamscy badacze określają jako proces „emancypacji umysłów”, który pozwala na większą wolność wypowiadania się oraz wyrażania poglądów krytycznych. Zmiana percepcji oraz nastawienia jest ważna, gdyż otwiera przestrzeń do debaty publicznej na temat demokracji oraz modeli życia i sposobu organizacji społeczeństwa. Dla mieszkańców Wietnamu, którym przez tysiące lat mówiono raczej, co mają robić, nie zaś, co mogą lub co wolno im robić, stanowi to duży wstrząs.

Aby zasady demokratyczne stopniowo przyjmowały się w społeczeństwie ustanowiono pewne ramy prawne, które mają stanowić swoisty „przewodnik” pokazujący obywatelom, w jaki sposób mogą korzystać z przysługujących im praw. Są to m.in.: Przepisy o decentralizacji; Rozporządzenie o sprawowaniu władzy demokratycznej we wspólnotach, dzielnicach i okręgach miejskich; Przepisy o sprawowaniu władzy demokratycznej w przedsiębiorstwach państwowych oraz Przepisy o sprawowaniu władzy demokratycznej w organizacjach państwowych. Spośród wymienionych szczególne znaczenie ma Rozporządzenie o sprawowaniu władzy demokratycznej we wspólnotach, dzielnicach i okręgach miejskich. Zostało ono ogłoszone przez Stały Komitet Zgromadzenia Narodowego 20 kwietnia 2007 r. (nr 34/2007/PL-UBTVQH11), a zastąpiło Przepisy o sprawowaniu władzy demokratycznej we wspólnotach, w połączeniu z Dekretem nr 29/1998/NDCP z 1998 r. oraz Dekretem nr 79/2003/ND-CP z dnia 7 lipca 2003 r. w tej samej kwestii. Nowe Rozporządzenie decentralizuje spory zakres władzy i deleguje jej sporo do władz lokalnych. Zwraca też ono szczególną uwagę na fakt, że centralnym elementem demokracji jest lud, zgodnie z jej mottem: „Lud wie, lud rozważa, lud nadzoruje i sprawdza". Rozporządzenie wymaga, by władze lokalne działały transparentnie, zwłaszcza przy podejmowaniu decyzji, jak również wyraźnie wskazuje obszary, które należy udostępnić opinii publicznej oraz poddać pod obywatelską dyskusję. Należą do nich:

- plany rozwoju społeczno-gospodarczego; programy gospodarczej restrukturyzacji oraz przewidywane roczne wydatki budżetowe, a także kwestie zasiedlania lokali na poziomie komunalnym;

- projekty inwestycyjne oraz ich wykonanie wraz z przyznawaniem im priorytetu, jak też harmonogramów realizacji; programy wspierania oraz rekompensaty w przypadkach konieczności przeznaczania jakichś terenów pod inwestycje i dokonywania przesiedleń mieszkańców w związku z realizacją projektów na poziomie komunalnym; opracowywanie szczegółowych planów zagospodarowania terenu i dostosowywanie projektów oraz planowania do zabudowy dzielnic zamieszkiwanych przez ludność lokalną; 
- zadania i zakres władzy przedstawicieli poziomu komunalnego oraz urzędników publicznych, którzy bezpośrednio zajmują się sprawami obywateli;

- wykorzystanie funduszy przeznaczonych na cele społeczne, inwestycje czy na pomoc finansową w ramach programów lub projektów przeznaczonych do realizacji na poziomie komunalnym (oraz zarządzanie nimi); wsparcie finansowe wszelkich projektów ze strony obywateli;

- przedsięwzięcia oraz plany pożyczania kapitału obywatelom na cele rozwoju produkcji, eliminacji głodu i zmniejszenia poziomu ubóstwa; sposoby i rezultaty analiz oraz typowania biednych gospodarstw domowych, które zdobywają prawa do pożyczek na cele rozwoju produkcji, do otrzymywania pomocy społecznej, pomocy przy budowie domów wspomaganych przez społeczeństwo, jak też dotacji do kart ubezpieczenia medycznego;

- plany tworzenia, łączenia lub podziału jednostek administracyjnych i dostosowywanie granic administracyjnych związane bezpośrednio z poziomem komunalnym;

- wyniki kontrolowania, weryfikowania oraz likwidowania przypadków negatywnych działań oraz korupcji ze strony przedstawicieli władz komunalnych lub funkcjonariuszy państwowych, władz wioskowych oraz komitetów uliczkowych (w miastach); wyniki głosowań nad wotum zaufania wobec przewodniczących oraz wiceprzewodniczących Rad Ludowych, prezesów i wiceprezesów Komitetów Ludowych szczebla komunalnego;

- treści i wyniki zaaprobowanych postulatów obywateli w kwestiach podlegających rozstrzygnięciu na poziomie komunalnym, przedłożonych do konsultacji obywatelskich przez administrację szczebla lokalnego, tak jak to określa artykuł 19 tego Rozporządzenia;

- płatności oraz ściągalność różnych opłat i kosztów, a także inne finansowe zobowiązania bezpośrednio wobec administracji szczebla komunalnego;

- przepisy prawne dotyczące procedur w przypadku decyzji administracji szczebla komunalnego w zakresie rozstrzygania spraw odnoszących się do obywateli;

- inne treści regulowane przepisami prawa, wymagane przez kompetentne organy państwowe lub uznane za konieczne przez administrację szczebla komunalnego ${ }^{8}$.

Na poziomie władz szczebla centralnego zasady demokratyczne zdają się stosowane w dość szerokim zakresie. Dzieje się tak, gdyż politycy i urzędnicy publiczni poziomu krajowego są lepiej wykształceni oraz politycznie świadomi niż osoby

${ }^{8}$ Stały Komitet Zgromadzenia Narodowego, Rozporządzenie w sprawie sprawowania władzy demokratycznej we wspólnotach, dzielnicach (jednostkach administracyjnych miasta) i okręgach miejskich, 20.04.2007, http://www.asianlii.org/vn/legis/laws/oeodicwat530/. 
pełniące porównywalne funkcje w prowincjach i władzach terenowych. Najbardziej widoczne zmiany nastąpiły w Zgromadzeniu Narodowym. Uzyskało ono znacznie większy zakres władzy w zakresie stanowienia prawa i nie traktuje się już przechodzenia dokumentów przez nie jako automatycznego „przykładania pieczęci”. Podczas odbywających się dwa razy w roku sesji Zgromadzenia Narodowego, na specjalnych posiedzeniach poświęconych interpelacjom deputowanych, członkowie rządu i ministrowie-kierownicy resortów otrzymują pytania, na które muszą odpowiadać, a posiedzenia są transmitowane przez telewizję. Ministrowie ponoszą przy tym odpowiedzialność za swoje wypowiedzi i obietnice składane w parlamencie. Mamy zatem do czynienia z wyraźnie większą dozą swobód w funkcjonowaniu tego najważniejszego organu władzy w Wietnamie.

Wietnamskie społeczeństwo stało się już realnie znacznie bardziej otwarte na prezentację różnych poglądów i idei. Obywatele mogą z większą swobodą stawać do wyborów do Zgromadzenia Narodowego, a niektórzy z nich odnoszą nawet zwycięstwo nad kandydatami nominowanymi przez partię rządzącą. Liczba deputowanych bezpartyjnych utrzymuje się na względnie stałym poziomie. Na przykład w Zgromadzeniu Narodowym IX kadencji było 8,35\% deputowanych bezpartyjnych, a w Zgromadzeniach X, XI oraz XII kadencji było ich odpowiednio: $15,11 \%, 10,24 \%$ i $8,72 \%{ }^{9}$.

Partia komunistyczna zdaje sobie sprawę, że nie powinna trzymać społeczeństwa twardą ręką. Aby rozwój kraju był możliwy, konieczne jest wprowadzenie pewnych form demokracji. Choć partia rządząca zachowuje swoją kierowniczą rolę oraz szeroki zakres władzy, a jej decyzje są przekładane na język obowiązującego prawa i wprowadzane w życie przez administrację państwową, to jednak nie jest już w stanie kierować administracją państwową i społeczeństwem w taki sposób, jak miało to miejsce w przeszłości. Niejako kompensując to, partia inicjuje reformy polityczne, które mają ułatwiać przeprowadzanie decentralizacji i demokratyzacji w stopniu, z jakim partia ta może się pogodzić. Wśród szeregowych członków partii dopuszcza się w szerszym zakresie prezentowanie opinii sprzecznych z przyjmowanymi, jeśli one nie wykraczają nazbyt poza linię partii. Biuro Polityczne dzieli się obecnie władzą z Sekretariatem i Stałym Komitetem Centralnym, w skład którego wchodzi ponad 160 członków. Przedstawiciele tych organów mogą kierować do członków Biura Politycznego pytania dotyczące spraw ich interesujących, żądać wyjaśnień i dalszych informacji. Tak więc dawniejszy monopol Biura Politycznego na podejmowanie decyzji w imieniu partii rządzącej uległ osłabieniu, a zakres władzy Stałego Komitetu Centralnego odpowiednio się rozszerzył.

${ }^{9}$ Quoc Hoi Nuoc Cong Hoa Xa Hoi Chu Nghia Viet Nam, Tu Lieu Bau Cu Quoc Hoi [Archiwum Wyborów do Zgromadzenia Narodowego], http:/www.na.gov.vn/htx/Vietnamese/C1454/?cateid=1455. 
Wraz z otwarciem Wietnamu na świat zewnętrzny w 1986 r. uwolnione zostały siły gospodarki rynkowej. Jej wpływ jest zaś odczuwany we wszystkich sferach życia. Poziom życia obywateli Wietnamu znacznie się poprawił. Produkt krajowy brutto (PKB) per capita w ujęciu nominalnym podniósł się z 80 USD w 1986 r. do 835 w 2008 r. ${ }^{10}$ Gospodarczy dobrobyt przekłada się na zwiększenie żądań demokratycznego zarządzania, co wiąże się również ze znacznie lepszym wykształceniem i poinformowaniem obywateli. Rośnie ich wiedza na temat polityki, regulacji prawnych oraz przysługujących im praw. Nie akceptują już dłużej sytuacji, kiedy mówi im się, co mają robić. Ludzie pragną więcej wolności i chcą, by ich głos oraz opinie były wysłuchiwane przez partię i rząd. Od pewnego czasu organizują się oni w różne grupy społeczne i zawodowe, których zadaniem jest przedkładanie swoich spraw decydentom.

Rewolucja informatyczna znacznie ułatwiła obywatelom dostęp do informacji, pomagając im zdobywać wiedzę o tym, co dzieje się wokół nich oraz w innych częściach kraju i świata. Według publikowanych przez Internet World Stats danych statystycznych, we wrześniu 2008 r. liczba użytkowników Internetu w Wietnamie wyniosła 20,2 mln, co dawało temu krajowi 6. pozycję w całej Azji. Dane te tym bardziej są imponujące, iż w porównaniu z rokiem 2000 liczba ich wzrosła ponad stukrotnie ${ }^{11}$. Wymiana wiadomości i informacji jest również możliwa dzięki abonentom telefonii komórkowej, których liczba do marca 2009 r. wynio-

${ }^{10}$ Według danych Banku Światowego w 2008 r. dochód narodowy (gross national income - GNI) per capita w Wietnamie według nominalnego bankowego przelicznika dolara wynosił 890 USD, lecz uwzględniając realną siłę nabywczą waluty miejscowej (przelicznika PPP), co w gospodarkach krajów rozwijających się jest znacznie dokładniejszą miarą, wynosił on 2700 USD. Patrz: World Development Indicators Database, World Bank, 1 July 2009. Natomiast w 1986 r. według przelicznika realnej siły nabywczej produkt krajowy brutto (PKB) per capita wynosił 733 USD, a GNI, który jest obliczany nieco inaczej, 957 USD. PKB Wietnamu per capita w 2005 r. wedle wskaźnika PPP wynosił jednak 3071 USD - dla następnych lat BŚ już nie wylicza PKB (patrz: dane Banku Światowego świetnie zarchiwizowane na stronie: www.nationmaster.com/graph/eco...). Produkt Wietnamu, wedle przelicznika PPP, wzrósł więc tym okresie per capita ponad trzykrotnie. Rzecz jasna realna poprawa życia była zapewne znacznie większa w związku z ogromną redukcją w tym okresie wydatków na wojsko. Można dodać, że wedle tych samych danych BŚ polski dochód per capita od 1986 do 2008 r. wzrósł trzykrotnie. W Wietnamie 2007 r. w stosunku do roku poprzedniego produkt krajowy brutto per capita wzrósł według Banku Światowego o 7,2\% i nie był to rok wyjątkowy. W tym samym roku kobiety średnio dożywały wieku 73 lata, a mężczyźni 68 lat, co jak na kraj rozwijający się było także wynikiem znakomitym (wiele krajów afrykańskich miało nadal średnią życia nieco ponad 40 lat, bogaty w ropę Kazachstan osiągał wskaźniki 61 i 72 lata, a nieco niższe wskaźniki od Wietnamu miały nawet Indie i Indonezja). Patrz: World Development Report 2009, Table 1, Key indicators of development, s. 353. Redakcja

${ }^{11}$ Le Nguyen, So Nguoi Dung Internet O Viet Nam Tang 100 Lan Sau 8 Nam [Liczba użytkowników Internetu w Wietnamie wzrosła stukrotnie w ciągu 8 lat] „VnExpress”, 5 September 2008, http://vnexpress.net/GL/Vi-tinh/2008/09/3BA062A7/. 
sła 73,2 mln, sytuując Wietnam ponownie na 6. miejscu w Azji ${ }^{12}$. Najnowsze informacje mogą być teraz rozpowszechniane w szerokim zakresie i do najodleglejszych miejsc poza kontrolą władz.

Coraz ważniejszą rolę w tworzeniu mostów między władzą rządzącą a obywatelami odgrywają media. Obecnie w Wietnamie funkcjonuje ponad 500 pozycji prasowych, publikowanych w różnych formach i językach. Prawie wszystkie prowincje i miasta mają swoje telewizje i rozgłośnie radiowe. Mimo że nie istnieją niezależne media, władze nie mogą dłużej ignorować lub nie doceniać roli mediów w społeczeństwie. W rzeczywistości media w Wietnamie przewodzą debacie nad demokratyzacją, zwłaszcza w dziedzinie transparentności i odpowiedzialności rządu. Jest to istotna tendencja prowadząca w kierunku otwartego społeczeństwa i znaczący postęp w kierunku formowania, choć powoli, społeczeństwa obywatelskiego w Wietnamie, które niewątpliwie przejawia się jeszcze w formach bardzo niedojrzałych.

Wietnam otworzył się na świat zewnętrzny prawie 20 lat temu i w tym czasie dokonał pełnej integracji ze światową gospodarką. Uzyskał członkostwo w międzynarodowych i regionalnych zgromadzeniach, takich jak: Stowarzyszenie Narodów Azji Południowo-Wschodniej (ASEAN), Wspólnota Gospodarcza Azji i Pacyfiku (APEC), Spotkania Państw Azji i Europy (ASEM), Światowa Organizacja Handlu (WTO), a także został wybrany (jako członek niestały) do Rady Bezpieczeństwa Narodów Zjednoczonych. Wietnam utrzymuje obecnie stosunki dyplomatyczne z 173 państwami oraz więzi ekonomiczne z ponad 160 państwami i terytoriami. Aby utrzymać wysoki wzrost gospodarczy, Wietnam polega w znacznej mierze na handlu zagranicznym, pomocy rozwojowej (ODA) oraz zagranicznych inwestycjach (FDI). W następstwie swojej integracji ze światem zewnętrznym Wietnam stanął w obliczu sił globalizacji i integracji ekonomicznej, w ramach których demokratyzacja wydaje się procesem nieuchronnym, jako że globalizacja nie pozwoli Wietnamowi pozostać w izolacji i nakazuje stosować te same zasady co inni. Na przykład, kiedy ASEAN przyjął swą Kartę z przepisem przewidującym utworzenie nowego organu, którego zadaniem będzie kontrola stosowania norm i poszanowania praw człowieka w każdym państwie członkowskim, Wietnam nie mógł odmówić wypełniania swoich zobowiązań także w tym aspekcie.

Naciski ze strony zagranicznych rządów i międzynarodowych organizacji miały niewątpliwie swój udział w demokratyzacji Wietnamu. Stosunki tego kraju z wieloma zagranicznymi partnerami uwarunkowane są poziomem transparentności i demokracji, co popycha kraj w kierunku zmian. Na wszystkich organizowanych w Wietnamie konferencjach dotyczących pomocy rozwojowej zagraniczni przed-

12 Vietnam Net/ICTNews, Vietnam Ranks 6th in Asia in Mobile Phone Users, ,VietnamNetBridge”, 21 July 2009, http://english.vietnamnet.vn/ITTelecom/2009/07/859322/. 
stawiciele zawsze domagają się poprawy jakości rządzenia (good governance), demokracji i poszanowania praw człowieka. Jako kraj rozwijający się Wietnam w jakiś sposób musi dostosowywać się do wymagań swoich darczyńców, aby uzyskać większe fundusze. Co więcej, w Wietnamie działa obecnie prawie 600 zagranicznych organizacji pozarządowych, spośród których wiele prowadzi projekty mające na celu zwiększenie świadomości demokratycznej obywateli, a także pomaga wietnamskiemu rządowi określić miejsce, jakie obywatele winni zająć w tym procesie. Innymi słowy, organizacje te odgrywają znaczącą rolę dla postępu w dziedzinie politycznej partycypacji obywateli. Zagraniczne ambasady i konsulaty generalne w Wietnamie również odgrywają pewną rolę, często przeprowadzając $\mathrm{w}$ terenie prace analityczne, które umożliwiają potwierdzenie, na ile wietnamskie władze realizują w praktyce swoją politykę demokratyzacji.

Wyraźnie wzrosła też wymiana osobowa z zagranicą. W 2008 r. do Wietnamu przyjechało 4,253 mln zagranicznych gości, wśród których ponad $2 \mathrm{mln}$ przybyło z krajów Zachodu, wliczając w to pół miliona Wietnamczyków posiadających obce obywatelstwo. Ponadto w ostatnich kilku latach zwiększyła się liczba Wietnamczyków studiujących za granicą. W roku akademickim 2005/2006 na przykład 4597 Wietnamczyków wyjechało z zamiarem podjęcia studiów w Stanach Zjednoczonych. Ich liczba w roku akademickim 2006/2007 wyniosła 6036. Podobnie w 2006 r. aż 6772 wietnamskich studentów jako miejsce studiów wybrało Australię, a do końca sierpnia 2007 r. wyjechało tam już 8315 studentów. Ta wysoka liczba osób przyjeżdżających i wyjeżdżających rozszerzyła znacznie zakres komunikacji między ludźmi oraz możliwości wymiany myśli, wywierając określony wpływ na całe społeczeństwo na jego drodze do demokracji.

Jednakże demokracja w Wietnamie napotyka pewne ograniczenia. Po pierwsze, w Wietnamie nadal brakuje całościowych ram prawnych, które zapewniałyby stosowanie reguł demokracji. Niektóre prawa i przepisy zachodzą na siebie, a nawet są ze sobą sprzeczne ${ }^{13}$. Nie istnieje wyraźna linia oddzielająca demokratyczne działania dozwolone przez prawo od działań, na które prawo nie pozwala. W tej sytuacji obywatelom trudno zrozumieć przysługujące im prawa i korzystać z nich. Prodemokratyczni aktywiści są z kolei łatwo i z byle powodu myleni z ,antyrządowymi dysydentami”, którzy z kolei muszą się liczyć z prawdopodobieństwem aresztowania, postawienia przed sądem i uwięzienia. Po drugie, wymiar sprawiedliwości nie jest precyzyjny ani efektywny. Niektóre przepisy prawne co prawda istnieją, lecz nie ma możliwości ich wypełniania. Nikt nie ponosi też odpowiedzialności za pogwałcenie zasad demokracji. Po trzecie, funkcjonariusze zobowiązani

${ }^{13}$ To Van Chau, Thuc Hien Dan Chu Trong Co Quan Nha Nuoc Va Mot So Kien Nghi [Stosowanie demokracji w organizacjach rządowych i niektóre propozycje], „Democracy and Laws”, January 2009, No. 202, s. 5-12. 
do nadzorowania procesu demokratyzacji nie wypełniają w pełni swoich obowiązków. Skłonni są raczej asekurować się, nie chcąc robić sobie wrogów wśród kolegów z rządowego establishmentu. W ten sposób próbują unikać konfrontacji. Po czwarte, Wietnamczycy sami niezbyt interesują się demokratyzacją kraju. Nie stanowi ona dla nich kwestii palącej ani priorytetowej. W ich codziennej egzystencji daleko ważniejsza jest raczej troska o podstawowe źródła utrzymania.

Od 1986 r. polityka doi moi przyspieszyła niewątpliwie zmiany gospodarcze, co skutkuje także przemianami demokratycznymi. Można wskazać tu przede wszystkim na rosnące znaczenie Zgromadzenia Narodowego oraz państwowej administracji [w stosunku do instancji partyjnych - Red.], połączone z wprowadzeniem zasad prawa i umacniania konstytucyjnego porządku prawnego, jak również na zwiększenie pluralizmu kulturowego, swobód obywatelskich, aktywności społecznej, wolności w różnych sferach życia, podobnie jak na zachodzące zmiany w systemie politycznym w kierunku jego większej transparentności i odpowiedzialności funkcjonariuszy za swe działania. Dotychczas jednak reformy te są wprowadzane jedynie odgórnie, jako że oddolny nacisk na zmiany demokratyczne pozostaje bardzo słaby, jeśli w ogóle jest obecny. Większość obywateli angażuje się przede wszystkim w działalność gospodarczą i poprawę poziomu życia swoich rodzin. Nowe dla nich zainteresowania polityczne oraz aspiracje mogą pojawić się później, tak jak miało to miejsce na Tajwanie i w Korei Południowej. Na tym wstępnym etapie, zarówno czynniki wewnętrzne, jak i zewnętrzne odgrywają ważną rolę, czasami wywierając nawet pewien nacisk, chociaż partia rządząca i władze nadal sprawują funkcje przywódcze.

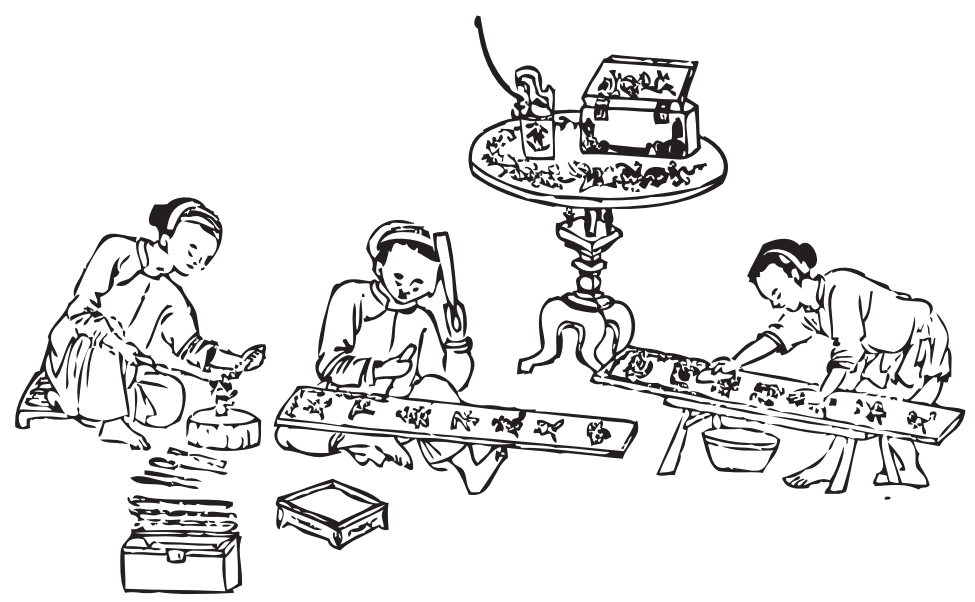

